\title{
Pemberdayaan Kader dan Dasawisma Dalam Pencegahan Kasus Demam Berdarah Dengue Di Banjar Menak, Kabupaten Gianyar, Provinsi Bali
}

\author{
Dewa Ayu Putu Ratna Juwita ${ }^{1}$, Luh Gede Pradnyawati ${ }^{2}$, Ni Made Hegard \\ Sukmawati ${ }^{3}$, Anny Eka Pratiwi ${ }^{4}$, Putu Nita Cahyawati ${ }^{5}$, Anak Agung Sri Agung \\ Aryastuti ${ }^{6}$, \\ Ni Nengah Wiryantini ${ }^{7}$ \\ 1,2,3,4 Bagian IKK-IKP Fakultas Kedokteran \& Ilmu Kesehatan Universitas Warmadewa, Denpasar \\ ${ }_{5,6}$ Bagian Farmakologi Fakultas Kedokteran \& Ilmu Kesehatan Universitas Warmadew \\ a, Denpasar \\ ${ }^{7}$ Bagian Patologi Klinik Fakultas Kedokteran \& Ilmu Kesehatan Universitas Warmadewa, Denpasar \\ Email: ratnajwtunwar@yahoo.com
}

\begin{abstract}
Abstrak
Banjar Menak terletak di Kabupaten Gianyar memiliki permasalahan kesehatan berupa peningkatan kasus Demam Berdarah Dengue (DBD) yang merupakan no.1 dari 10 besar penyakit pasien rawat inap di RS dengan angka insiden tahun 2015 adalah sebesar 442,3 per 100.000 penduduk. Selama ini pemberdayaan masyarakat untuk melakukan surveilans jentik dan PSN mandiri belum pernah digalakkan, karena itu kami melakukan pemberdayaan kepada kader dan dasawisma untuk melaksanakan program tersebut. Metode yang digunakan adalah metode pelatihan dan pendampingan untuk meningkatkan pengetahuan dan keterampilan mitra tentang DBD, surveilans jentik, dan PSN. Kegiatan dilakukan oleh 3 orang kader dan 3 orang dasawisma. Hasil pretest tingkat pengetahuan mitra sebesar $71,7 \%$ dan post-test $88 \%$. Hasil analisis FGD didapatkan gambaran bahwa mitra belum memiliki pemahaman yang benar tentang DBD, surveilans jentik dan PSN. Dari hasil observasi dan penilaian mingguan didapatkan penurunan nilai trend Container Indeks $(\mathrm{CI})$ pada keenam mitra dengan hasil: mitra 1 dari 9,1 minggu I menjadi 1,8 pada minggu IV; mitra 2 dari 10,9 menjadi 1,8; mitra 3 dari 14,6 menjadi 0; mitra 4 dari 10,9 menjadi 3,6; mitra 5 dari 49,1 menjadi 3,6; mitra 6 dari 20,2 menjadi 1,8. Secara umum, nilai CI dan Density Figure (DF) semua KK binaan mitra sudah mengalami penurunan. Kegiatan $\mathrm{PkM}$ ini dinilai sudah berhasil sesuai luaran indikator. Hal ini mengindikasikan sudah berjalan baiknya KIE PSN yang. Saran yang dapat disampaikan adalah agar kedua kelompok mitra dapat menjadi ujung tombak penanggulangan kasus DBD di Banjar Menak pada khususnya dengan memberdayakan masyarakat untuk melakukan surveilans jentik mandiri dan PSN yang benar.
\end{abstract}

Kata Kunci: Demam Berdarah Dengue, surveilans, Container Indeks, Density Figure

\author{
Abstract \\ [Empowerment Of Cadres And Dasawisma In Dengue Haemorrhagic Fever Cases Prevetion at Banjar Menak, \\ Gianyar Regency, Bali]
}

Located in Gianyar Regency, Banjar Menak was experiencing in dengue cases. Dengue Haemorrhagic Fever (DHF) is one of the top ten most frequent inpatient disease in Gianyar, with incidence of 442,3 in 100.000 people (2015). The mosquito larva surveillance and mosquito nest eradication had not been well implemented in the area, there for, we conducted a comunity involvement program with the aim to increase the knowledge and the skill of the resident on dengue and its eradication measures. The method of the program was cadre trainning on knowledge of dengue, mosquito larvae surveillance, and mosquito net eradication program. (known as PSN). This trainning was participated by three cadre and three dasawisma of Banjar Menak. The pre-test on the knowledge of the participantis was 71,7\% while the post-test was $88 \%$. The participants were not well euiped with understanding on dengue, larvae surveillance, and PSN as it shown on FGD analysis. The weekly post program observation showed a decreasing trend on Container Index (CI) for 
all the participants's surveillance area. The CI of week 1 and 4 for each participantss were 9,1 to 1,8; 10,9 to 1,$8 ; 14,6$ to $0 ; 10,9$ to 3,$6 ; 49,1$ to 3,6 ; and 20,2 to 1,8 .

In general, the CI and Density Figure (DF) in Banjar Menak has decreased.The program has achieved its external indicator and deemed as success. The trained cadre and dasawisma is expecting to be the front runner for the community involvement in dengue eradication program in Banjar Menak.

Key words: Dengue Haemorrhagic Fever, surveillance, Container Index, Density Figure

\section{PENDAHULUAN}

Banjar Menak terletak di Desa Tulikup, Kabupaten Gianyar dengan luas wilayah $5 \mathrm{~km}^{2}$ dan jumlah penduduk 750 orang $(300 \mathrm{KK})$ dan kepadatan penduduk 1,81 jiwa per $\mathrm{km}^{2}$. Banjar Menak berada pada ketinggian $250 \mathrm{~km}$ di atas permukaan laut dengan kontur geografis yang landai ${ }^{[1]}$

Kasus DBD di Kabupaten Gianyar menempati tempat teratas dari 10 besar penyakit pada pasien rawat inap di RSU. Angka insiden DBD di Kabupaten Gianyar pada tahun 2015 adalah sebesar 442,3 per 100.000 penduduk dengan Case Fatality Rate (CFR) 0\%. Jika dilihat dalam 5 tahun terakhir, angka insiden DBD mengalami peningkatan yang cukup signifikan, yaitu dari 44,3 per 100.000 penduduk pada tahun 2011 menjadi 442,3 per 100.000 penduduk pada tahun 2015. Angka ini berada jauh di atas target nasional DBD yaitu sebesar 49 per 100.000 penduduk. Walaupun promosi kesehatan, surveilan DBD maupun surveilan jentik telah gencar dilakukan, namun kasus DBD selalu mengalami peningkatan. Kemenkes telah menetapkan program penanggulangan DBD sesuai kondisi di wilayah tersebut, seperti: Pemberantasan Sarang Nyamuk (PSN) namun dari data terakhir tahun 2015, Angka Bebas Jentik (ABJ) justru berada pada titik terendah dengan angka insiden DBD tertinggi dalam 5 tahun terakhir ini $[2,3,4,5,6]$.

Masalah kesehatan prioritas di daerah mitra adalah tingginya angka insiden DBD. Tingginya angka insiden DBD ini dikarenakan oleh rendahnya Angka Bebas Jentik (ABJ) dalam 5 tahun terakhir ini. Rendahnya ABJ tersebut salah satunya disebabkan oleh rendahnya partisipasi masyarakat dalam Pemberantasan Sarang Nyamuk (PSN) dan belum adanya partisipasi tatanan sosial setempat dalam melakukan surveilans jentik mandiri dan
PSN. Dalam upaya pengendalian jentik, nyamuk dan upaya penurunan angka insiden DBD, belum ada penyuluhan yang tdilakukan ke masing-masing rumah tangga, baik dari Puskesmas maupun Pustu yang membawahi kader kesehatan itu sendiri.

Masyarakat di Banjar Menak memiliki potensi tatanan masyarakat sebagai modalitas dalam penggerakan pengendalian DBD berbasis masyarakat. Hal ini dapat menjadi potensi tersendiri dalam menggerakkan program pengendalian DBD secara aktif, terutama melalui peran aktif PKK Dasa wisma dan kader dalam bentuk pelatihan dan pendampingan.

Mitra tim pengabdian adalah PKK Dasa Wisma dan kader. Permasalahan yang ditemukan pada kedua mitra tersebut adalah belum adanya peran serta kedua mitra dalam keikutsertaan sebagai penggerak penanggulangan DBD yang langsung bersentuhan dengan masyarakat. Selama ini pemantauan jentik tidak dilakukan oleh mitra, namun oleh jumantik yang ditetapkan sendiri oleh Dinas Kesehatan Kabupaten Gianyar. Dengan memberdayakan dasawisma dan kader dalam pemantauan jentik, diharapkan dapat membantu tugas jumantik dalam pencatatan pelaporan jentik plus langsung melakukan intervensi berupa Komunikasi, Edukasi dan Informasi (KIE) tentang PSN di masing-masing $\mathrm{KK}$ yang diampunya $[5,6,8,9,10]$.

\section{METODE}

Metode pelaksanaan kegiatan berupa pelatihan dan pendampingan, yang meliputi:

Sosialisasi dengan kader dan PKK dasa wisma berupa koordinasi dengan pihak kader dan dasa wisma mengenai program

Pertemuan Focus Group Discussion 
(FGD) dengan mitra untuk melakukan problem identification and problem solving oleh mitra itu sendiri

Penyuluhan dan dialog interaktif tentang DBD dan PSN dengan memberikan slide tentang DBD dan PSN serta pelatihan pengisian form jentik dan form pelaksanaan PSN yang benar.

Pelatihan mitra dalam surveilans jentik

Pelatihan Mitra dalam Pemberantasan Sarang Nyamuk (PSN) yang benar

Evaluasi akhir untuk membandingkan pengetahuan dan keterampilan mitra dalam pemantauan jentik dan pelaksanaan PSN yang benar.

HASIL

Pelaksanaan kegiatan meliputi:

Pengarahan Pendahuluan

Kegiatan ini dihadiri oleh 3 orang anggota PKK dan 3 orang dasawisma yang dipilih oleh kepala Banjar Menak. Tingkat kehadiran kedua mitra adalah $100 \%$.

\section{Pret-test dan post-test}

Pre-test dan post test dilakukan menggunakan kuesioner dengan 10 buah pertanyaan mencakup: gambaran umum tentang DBD, rantai penularan, rantai pemberantasan, surveilans jentik dan PSN. Hasil pre dan post-test ke enam anggota mitra tentang DBD mengalami peningkatan.

\section{Focus Group Discussion (FGD)}

Terdiri dari 6 orang, dengan komposisi yang dijabarkan sebagai berikut: Pada tahap ini, diskusi mencakup: definisi, epidemiogi, gejala/penanganan, rantai penularan, perilaku yang meningkatkan risiko penularan, surveilans jentik, program pemerintah, pemberdayaan masyarakat terkait program, dan PSN DBD. Hasil dari FGD adalah sebagai berikut:

Semua mitra sudah mengetahui secara umum definisi, epidemiologi, dan gejala DBD. Berikut kutipannya:

" $D B D$ adalah penyakit yang disebabkan oleh virus dan ditularkan oleh nyamuk Aedes".

..."setiap tahun pasti ada kasusnya, biasanya musim -musim hujan".

...."kalo gejalanya sih demam pasti, muntah, pokoknya isi bintik-bintik itu pasti gejala $D B$ ".

Belum semua mitra mengetahui secara jelas rantai penularan nyamuk Aedes agypti. Berikut kutipannya:

“....pokoknya semua nyamuk itu nyamuk Aedes, apalagi yang belang-belang. Tidurnya di air bersih yang menggenang, air yang mengalir juga bisa."

"Jentik nyamuk itu bentuknya seperti ulat kelebit-kelebit di air, biasanya di tempat pemandian burung atau di vas-vas bunga"

"Nyamuknya di kolong tempat tidur biasanya, di gantungan baju, dan air yang menggenang"

Semua mitra belum mengetahui perilaku yang meningkatkan risiko penularan DBD secara spesifik. Berikut kutipannya:

"....Perilaku yang kurang bersih, musim pancaroba juga pasti meningkat penyakitnya, kamar mandi kotor, dan sistem kekebalan tubuh yang lemah"

Semua mitra belum mengetahui tentang surveilans jentik. Berikut kutipannya:

"Surveilans jentik itu ngitung jumlah nyamuk kayaknya. Jadi kita bisa tahu berapa ada nyamuk penular penyakit di rumah"

"yang jadi surveilans harusnya kita sendiri di rumah..ya tapi kan ribet masak ngitungin nyamuk"

Semua mitra belum mengetahui program pemerintah terkait penanggulangan DBD. Mitra hanya tahu dari media elektronik dan jumantik yang hanya bertugas menghitung jentik. Belum ada pemberdayaan keluarga yang terkoordinir untuk melakukan pemantauan 
jentik swadaya. Berikut kutipannya: “..program pemerintah mungkin yang di tipi itu aja biar masyarakat tahu.... ya 3M itu dah" ."kalau dari puskesmas kayaknya belum ada ya..Cuma ada jumantik aja yang suka datang ke rumah-rumah ngitung jentik-jentik itu aja. Ndak ada ngomong apa, Cuma ngitung aja trus pergi."

"Semua mitra sudah mengetahui cara pemberantasan sarang nyamuk (PSN), namun tidak terstruktur dan tidak pernah menerapkan secara rutin. Berikut kutipannya:

\section{"...Pake obat nyamuk bakar, semprot, rajin menguras bak mandi, pake kelambu dan memakai autan"}

Penyebab masih meningkatnya angka insiden DBD dari semua mitra mengatakan bahwa karena faktor masyarakatnya sendiri yang malas melakukan PSN secara rutin, disamping banyak juga yang tidak mengetahui apa itu PSN. Berikut kutipannya:

\section{“...Ya..ndak ada yang tau apa} itu PSN kayaknya. Gak pernah ada sosialisasi ke masyarakat. Kalo kader paling pas pertemuan di Puskesmas tapi waktu ndak membicarakan DBD.

Diselip-selipin lah sekedar pas akhir acara".

Solusi yang ditawarkan oleh mitra itu sendiri untuk menanggulangi peningkatan angka insiden DBD setiap tahunnya adalah dengan memberikan penyuluhan kepada masyarakat tentang penanggulangan DBD, menggerakkan masyarakat dan melakukan monitoring rutin. Berikut kutipannya:

“........masyarakat itu kebanyakan tidak tahu gimana cara memberantas DBD, dok. Gimana cara melakukan PSN, 3M PLUS itu gaktau masyarakat. Saya juga kurang begitu tahu kalau ndak ikut kegiatan dokter yang kayak gini ini".

".......semua kan tergantung masyarakatnya. Walaupun pemerintah nanti wantiwanti tapi kalau masyarakatnya ndakmau ya tetep saja DBD terus meningkat. Jadi menurut saya ya harus swadaya, gotong royong tiap minggu itu digalakkan disisipin PSN ini."

"...........tapi ya harus rutin ya, jangan sekali tempo saja. Minimal kelian banjar harus memonitor terus agar kegiatan tiap minggu itu memang berjalan. Kalau menunggu orang puskesmas datang, sampai kapanpun tetep saja DBD terus naik tiap tahun"

\section{Penyuluhan dan dialog interaktif tentang DBD dan PSN.}

Penyuluhan tentang DBD dan PSN dilaksanakan dengan metode dialog interaktif langsung.

\section{Pelatihan pengisian form pemantauan jentik}

Pelatihan pengisiaan form jumantik dilakukan dengan membagikan buku saku DBD dan form isian pemantauan jentik mingguan sambil melaksanakan diskusi terkait isian.

\section{Pembagian kit pemantau jentik}

Kit pemantau jentik yang dibagikan ke mitra berupa 6 buah senter dan 6 form pemantauan jentik mingguan berkala.

\section{Pelaksanaan Post-test}

Post-test dilaksanakan untuk mengetahui seberapa besar peningkatan pengetahuan mitra tentang DBD, surveilans dan jentik, dan PSN yang benar setelah dilakukan penyuluhan.

Pelaksanaan Pemantauan Jentik dan 
PSN

Pemantauan jentik dan PSN dilaksanakan oleh masing-masing mitra secara berkala mingguan terhadap $5 \mathrm{KK}$ yang dipilih oleh masing-masing mitra. Kegiatan PJB ini juga disertai dengan KIE oleh mitra terhadap KK terkait hasil yang diperoleh berdasarkan perhitungan dari form isian. Pelaksanaan dilaksanakan berdasarkan formulir yang telah disiapkan oleh tim PkM. Indikator keberhasilan pelaksanaan PJB adalah kelengkapan form buku log PJB pada pemantauan berkala. Hasil Pemantauan Jentik Berkala (PJB) dari masing-masing $\mathrm{KK}$ dapat dilihat pada tabel dan grafik berikut ini:

Tabel 1. Tabel Pemantauan Jentik Berkala Kader 1

\begin{tabular}{|c|c|c|c|c|c|c|c|c|c|}
\hline \multirow{2}{*}{$\begin{array}{c}\text { Nama } \\
\text { KK }\end{array}$} & \multirow{2}{*}{$\begin{array}{c}\text { Jumlah } \\
\text { Kontainer }\end{array}$} & \multicolumn{2}{|c|}{ Minggu ke-1 } & \multicolumn{2}{|c|}{ Minggu ke-2 } & \multicolumn{2}{|c|}{ Minggu ke- 3} & \multicolumn{2}{|c|}{ Minggu ke-4 } \\
\hline & & $\begin{array}{c}\text { Kontainer } \\
\text { Terindikasi } \\
\end{array}$ & $\begin{array}{l}\text { CI } \\
(\%)\end{array}$ & $\begin{array}{l}\text { Kontainer } \\
\text { Terindikasi }\end{array}$ & $\begin{array}{c}\mathrm{CI} \\
(\%)\end{array}$ & $\begin{array}{c}\text { Kontainer } \\
\text { Terindikasi } \\
\end{array}$ & $\begin{array}{c}\mathrm{CI} \\
(\%) \\
\end{array}$ & $\begin{array}{c}\text { Kontainer } \\
\text { Terindikasi } \\
\end{array}$ & $\begin{array}{c}\mathrm{CI} \\
(\%) \\
\end{array}$ \\
\hline & 11 & 1 & 9,1 & 1 & 9,1 & 0 & 0 & 0 & 0 \\
\hline KK 2 & 11 & 1 & 9,1 & 1 & 9,1 & 1 & 9,1 & 0 & 0 \\
\hline KK 3 & 11 & 1 & 9,1 & 1 & 9,1 & 0 & 0 & 1 & 9,1 \\
\hline KK 4 & 11 & 1 & 9,1 & 1 & 9,1 & 1 & 9,1 & 0 & 0 \\
\hline KK 5 & 11 & 1 & 9,1 & 1 & 9,1 & & 9,1 & 0 & 0 \\
\hline \multicolumn{2}{|c|}{ House Indeks } & $100 \%$ & & \multicolumn{2}{|c|}{$100 \%$} & \multicolumn{2}{|l|}{$60 \%$} & \multicolumn{2}{|l|}{$20 \%$} \\
\hline \multicolumn{5}{|c|}{$\begin{array}{l}\text { Berdasarkan tabel di atas dapat dilihat } \\
\text { bahwa dari } 5 \mathrm{KK} \text { binaan kader } 1 \text {, rata-rata } \\
\text { pemeriksaan mencakup } 11 \text { kontainer. Hasil } \\
\text { pemeriksaan kontainer rata-rata } 5 \mathrm{KK} \text { pada } \\
\text { minggu I dan II adalah } 9,1 \% \text { kontainer } \\
\text { terindikasi jentik dengan kontainer indeks } \\
\text { rata-rata } 9,1 \% \text { dan HI } 100 \% \text {. Hasil } \\
\text { pemeriksaan kontainer rata-rata } 5 \mathrm{KK} \text { pada }\end{array}$} & $\begin{array}{l}\text { ming } \\
\text { terind } \\
\text { rata-r } \\
\text { mings } \\
\text { rata-r } \\
\text { jentik } \\
9,1 \%\end{array}$ & $\begin{array}{l}\text { u III a } \\
\text { kasi jentik } \\
\text { ta } 5,5 \% \text { da } \\
\text { u ke IV, ha } \\
\text { ta adalah } 1 \\
\text { dengan k } \\
\text { lan HI } 20 \%\end{array}$ & $\begin{array}{l}\text { lah } \\
\text { lengan } \\
\text { HI } 60 \\
1 \text { pem } \\
3 \% \text { ko } \\
\text { atainer }\end{array}$ & $\begin{array}{l}5,5 \% \text { ko } \\
\text { kontainer } \\
\% \text {. Sedang } \\
\text { eriksaan ko } \\
\text { ntainer teri } \\
\text { indeks r }\end{array}$ & $\begin{array}{l}\text { tainer } \\
\text { ldeks } \\
\text { an di } \\
\text { tainer } \\
\text { dikasi } \\
\text { a-rata }\end{array}$ \\
\hline & & & el 2 & mantauan Jeı & $\mathrm{ik} \mathrm{Ber}$ & ala Kader 2 & & & \\
\hline Nama & Jumlah & Minggu $\mathrm{k}$ & & Minggu $\mathrm{k}$ & & Minggu $k$ & & Minggu & \\
\hline KK & Kontainer & $\begin{array}{l}\text { Kontainer } \\
\text { Terindikasi }\end{array}$ & $\begin{array}{c}\mathrm{CI} \\
(\%)\end{array}$ & $\begin{array}{l}\text { Kontainer } \\
\text { Terindikasi }\end{array}$ & $\begin{array}{c}\mathrm{CI} \\
(\%)\end{array}$ & $\begin{array}{l}\text { Kontainer } \\
\text { Terindikasi }\end{array}$ & $\begin{array}{c}\mathrm{CI} \\
(\%)\end{array}$ & $\begin{array}{l}\text { Kontainer } \\
\text { Terindikasi }\end{array}$ & $\begin{array}{c}\mathrm{CI} \\
(\%)\end{array}$ \\
\hline KK 1 & 11 & 1 & 9,1 & 1 & 9,1 & 0 & 0 & 0 & 0 \\
\hline KK 2 & 11 & 0 & 0 & 0 & 0 & 0 & 0 & 0 & 0 \\
\hline KK 3 & 11 & 3 & 27,3 & 2 & 18,2 & 1 & 9,1 & 1 & 9,1 \\
\hline KK 4 & 11 & 1 & 9,1 & 2 & 18,2 & 2 & 18,2 & 0 & 0 \\
\hline KK 5 & 11 & 1 & 9,1 & 1 & 9,1 & 1 & 9,1 & 0 & 0 \\
\hline House I & adeks & $80 \%$ & & $80 \%$ & & $60 \%$ & & $20 \%$ & \\
\hline
\end{tabular}

Dari tabel di atas dapat dilihat bahwa dari 5 KK binaan kader 2, rata-rata pemeriksaan mencakup 11 kontainer. Hasil pemeriksaan kontainer rata-rata $5 \mathrm{KK}$ pada minggu I dan II adalah 10,9\% kontainer terindikasi jentik pada minggu I dan II dengan HI $80 \%$. Hasil pemeriksaan kontainer rata-rata $5 \mathrm{KK}$ pada minggu III 
adalah 7,3\% kontainer terindikasi jentik dengan HI $60 \%$. Sedangkan di minggu ke IV, hasil pemeriksaan kontainer rata-rata adalah 1,8\% kontainer terindikasi jentik HI $20 \%$.

Tabel 3. Tabel Pemantauan Jentik Berkala Kader 3

\begin{tabular}{|c|c|c|c|c|c|c|c|c|c|}
\hline \multirow{2}{*}{$\begin{array}{c}\text { Nama } \\
\text { KK }\end{array}$} & \multirow{2}{*}{$\begin{array}{c}\text { Jumlah } \\
\text { Kontainer }\end{array}$} & \multicolumn{2}{|c|}{ Minggu ke-1 } & \multicolumn{2}{|c|}{ Minggu ke-2 } & \multicolumn{2}{|c|}{ Minggu ke- 3} & \multicolumn{2}{|c|}{ Minggu ke-4 } \\
\hline & & $\begin{array}{l}\text { Kontainer } \\
\text { Terindikasi }\end{array}$ & $\begin{array}{l}\text { CI } \\
(\%)\end{array}$ & $\begin{array}{l}\text { Kontainer } \\
\text { Terindikasi }\end{array}$ & $\begin{array}{r}\text { CI } \\
(\%)\end{array}$ & $\begin{array}{l}\text { Kontainer } \\
\text { Terindikasi }\end{array}$ & $\begin{array}{l}\text { CI } \\
(\%)\end{array}$ & $\begin{array}{l}\text { Kontainer } \\
\text { Terindikasi }\end{array}$ & $\begin{array}{c}\text { CI } \\
(\%)\end{array}$ \\
\hline KK 1 & 11 & 2 & 18,2 & 0 & 0 & 0 & 0 & 0 & 0 \\
\hline KK 2 & 11 & 1 & 9,1 & 0 & 0 & 0 & 0 & 0 & 0 \\
\hline KK 3 & 11 & 2 & 18,2 & 1 & 9,1 & 1 & 9,1 & 0 & 0 \\
\hline KK 4 & 11 & 2 & 18,2 & 0 & 0 & 0 & 0 & 0 & 0 \\
\hline KK 5 & 11 & 1 & 9,1 & 0 & 0 & 0 & 0 & 0 & 0 \\
\hline Hous & $\operatorname{deks}(\mathrm{HI})$ & $100^{\circ}$ & & $20 \%$ & & $20 \%$ & & $0 \%$ & \\
\hline
\end{tabular}

Dari tabel di atas dapat dilihat bahwa dari 5 KK binaan kader 3, rata-rata pemeriksaan mencakup 11 kontainer/ TPA pemeriksaan sesuai dengan form PJB. Hasil pemeriksaan kontainer rata-rata $5 \mathrm{KK}$ pada minggu I adalah $14,6 \%$ terindikasi jentik dengan HI 100\%; pada minggu II adalah
1,8\% terindikasi jentik dengan HI 20\%; pada minggu III adalah $1,8 \%$ kontainer terindikasi jentik dengan HI 20\%; dan pada minggu ke IV, hasil pemeriksaan kontainer rata-rata adalah $0 \%$ kontainer terindikasi jentik dengan $\mathrm{HI} 0 \%$

Tabel 4. Tabel Pemantauan Jentik Berkala Dasawisma 1

\begin{tabular}{|c|c|c|c|c|c|c|c|c|c|}
\hline \multirow{2}{*}{$\begin{array}{c}\text { Nama } \\
\text { KK }\end{array}$} & \multirow{2}{*}{$\begin{array}{c}\text { Jumlah } \\
\text { Kontainer }\end{array}$} & \multicolumn{2}{|c|}{ Minggu ke-1 } & \multicolumn{2}{|c|}{ Minggu ke-2 } & \multicolumn{2}{|c|}{ Minggu ke- 3} & \multicolumn{2}{|c|}{ Minggu ke-4 } \\
\hline & & $\begin{array}{c}\text { Kontainer } \\
\text { Terindikasi }\end{array}$ & $\begin{array}{l}\text { CI } \\
(\%) \\
\end{array}$ & $\begin{array}{c}\text { Kontainer } \\
\text { Terindikasi } \\
\end{array}$ & $\begin{array}{l}\text { CI } \\
(\%) \\
\end{array}$ & $\begin{array}{c}\text { Kontainer } \\
\text { Terindikasi } \\
\end{array}$ & $\begin{array}{c}\mathrm{CI} \\
(\%) \\
\end{array}$ & $\begin{array}{c}\text { Kontainer } \\
\text { Terindikasi }\end{array}$ & $\begin{array}{l}\mathrm{CI} \\
(\%) \\
\end{array}$ \\
\hline KK 1 & 11 & 1 & 9,1 & 0 & 0 & 0 & 0 & 0 & 0 \\
\hline KK 2 & 11 & 1 & 9,1 & 1 & 9,1 & 1 & 9,1 & 0 & 0 \\
\hline KK 3 & 11 & 2 & 18,2 & 2 & 18,2 & 2 & 18,2 & 1 & 9,1 \\
\hline KK 4 & 11 & 1 & 9,1 & 1 & 9,1 & 1 & 9,1 & 1 & 9,1 \\
\hline KK 5 & 11 & 1 & 9,1 & 0 & 0 & 1 & 9,1 & 0 & 0 \\
\hline $\mathrm{Hol}$ & Indeks & $100 \%$ & & $80 \%$ & & $80 \%$ & & $40 \%$ & \\
\hline
\end{tabular}

Dari tabel di atas dapat dilihat bahwa dari $5 \mathrm{KK}$ binaan dasawisma 1, rata-rata pemeriksaan mencakup 11 kontainer. Hasil pemeriksaan kontainer rata-rata $5 \mathrm{KK}$ pada minggu I adalah 10,9\% terindikasi jentik dengan HI 100\%; pada minggu II adalah
7,3\% terindikasi jentik dengan $\mathrm{HI} 80 \%$; pada minggu III adalah 3,6\% kontainer terindikasi jentik dengan n $\mathrm{HI} 80 \%$; dan pada minggu ke IV, hasil pemeriksaan kontainer rata-rata adalah $0 \%$ kontainer terindikasi jentik dengan $\mathrm{HI} 40 \%$. 
Tabel 5 . Tabel Pemantauan Jentik Berkala Dasawisma 2

\begin{tabular}{|c|c|c|c|c|c|c|c|c|c|}
\hline \multirow{2}{*}{$\begin{array}{c}\text { Nama } \\
\text { KK }\end{array}$} & \multirow{2}{*}{$\begin{array}{c}\text { Jumlah } \\
\text { Kontainer }\end{array}$} & \multicolumn{2}{|c|}{ Minggu ke-1 } & \multicolumn{2}{|c|}{ Minggu ke-2 } & \multicolumn{2}{|c|}{ Minggu ke- 3} & \multicolumn{2}{|c|}{ Minggu ke-4 } \\
\hline & & $\begin{array}{l}\text { Kontainer } \\
\text { Terindikasi }\end{array}$ & $\begin{array}{c}\text { CI } \\
(\%)\end{array}$ & $\begin{array}{l}\text { Kontainer } \\
\text { Terindikasi }\end{array}$ & $\begin{array}{c}\text { CI } \\
(\%)\end{array}$ & $\begin{array}{l}\text { Kontainer } \\
\text { Terindikasi }\end{array}$ & $\begin{array}{l}\mathrm{CI} \\
(\%)\end{array}$ & $\begin{array}{l}\text { Kontainer } \\
\text { Terindikasi }\end{array}$ & $\begin{array}{l}\mathrm{CI} \\
(\%)\end{array}$ \\
\hline KK 1 & 11 & 5 & 45,5 & 0 & 45,5 & 4 & 36,4 & 0 & 0 \\
\hline KK 2 & 11 & 6 & 54,6 & 5 & 45,5 & 0 & 0 & 0 & 0 \\
\hline KK 3 & 11 & 6 & 54,6 & 3 & 27,3 & 0 & 0 & 1 & 9,1 \\
\hline KK 4 & 11 & 6 & 54,6 & 5 & 45,5 & 0 & 0 & 1 & 9,1 \\
\hline KK 5 & 11 & 4 & 36,4 & 4 & 36,4 & 2 & 18,2 & 0 & 0 \\
\hline House & leks (HI) & $100 \%$ & & $100 \%$ & & $40 \%$ & & $40 \%$ & \\
\hline
\end{tabular}

Dari tabel di atas dapat dilihat bahwa dari $5 \mathrm{KK}$ binaan dasawisma 2, rata-rata pemeriksaan mencakup 11 kontainer. Hasil pemeriksaan kontainer rata-rata $5 \mathrm{KK}$ pada minggu I cukup tinggi, yaitu 49,14\% terindikasi jentik dengan HI 100\%; pada minggu II adalah $30,9 \%$ terindikasi jentik dengan HI 100\%; pada minggu III adalah $10,9 \%$ kontainer terindikasi jentik dengan HI 40\%; dan pada minggu ke IV, hasil pemeriksaan kontainer rata-rata adalah $3,6 \%$ kontainer terindikasi jentik dengan HI $40 \%$.

Tabel 6 . Tabel Pemantauan Jentik Berkala Dasawisma 3

\begin{tabular}{|c|c|c|c|c|c|c|c|c|c|}
\hline \multirow{2}{*}{$\begin{array}{c}\text { Nama } \\
\text { KK }\end{array}$} & \multirow{2}{*}{$\begin{array}{c}\text { Jumlah } \\
\text { Kontainer }\end{array}$} & \multicolumn{2}{|c|}{ Minggu ke-1 } & \multicolumn{2}{|c|}{ Minggu ke-2 } & \multicolumn{2}{|c|}{ Minggu ke- 3} & \multicolumn{2}{|c|}{ Minggu ke-4 } \\
\hline & & $\begin{array}{c}\text { Kontainer } \\
\text { Terindikasi }\end{array}$ & $\begin{array}{l}\text { CI } \\
(\%)\end{array}$ & $\begin{array}{c}\text { Kontainer } \\
\text { Terindikasi }\end{array}$ & $\begin{array}{c}\mathrm{CI} \\
(\%) \\
\end{array}$ & $\begin{array}{c}\text { Kontainer } \\
\text { Terindikasi }\end{array}$ & $\begin{array}{c}\mathrm{CI} \\
(\%) \\
\end{array}$ & $\begin{array}{c}\text { Kontainer } \\
\text { Terindikasi }\end{array}$ & $\begin{array}{c}\mathrm{CI} \\
(\%) \\
\end{array}$ \\
\hline KK 1 & 11 & 1 & 9,1 & 0 & 0 & 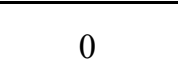 & $0 \%$ & 0 & 0 \\
\hline KK 2 & 11 & 2 & 18,2 & 1 & 9,1 & 0 & $0 \%$ & 0 & 0 \\
\hline KK 3 & 11 & 2 & 18,2 & 0 & 0 & 0 & $0 \%$ & 1 & 9,1 \\
\hline KK 4 & 11 & 4 & 36,4 & 3 & 27,3 & 0 & $0 \%$ & 0 & 0 \\
\hline KK 5 & 11 & 2 & 18,2 & 1 & 9,1 & 0 & $0 \%$ & 0 & 0 \\
\hline $\mathrm{Hou}$ & Indeks & $100 \%$ & & $60 \%$ & & $0 \%$ & & $20 \%$ & \\
\hline
\end{tabular}

Dari tabel di atas dapat dilihat bahwa dari $5 \mathrm{KK}$ binaan dasawisma 3, rata-rata pemeriksaan mencakup 11 kontainer. Hasil pemeriksaan kontainer rata-rata $5 \mathrm{KK}$ pada minggu I cukup tinggi, yaitu 20\% terindikasi jentik dengan HI 100\%; pada minggu II adalah 9,1\% terindikasi jentik HI
$60 \%$; pada minggu III adalah $0 \%$ kontainer terindikasi jentik dengan kontainer indeks rata-rata $0 \%$ dan $\mathrm{HI} 0 \%$; dan pada minggu ke IV, hasil pemeriksaan kontainer ratarata adalah 3,6\% kontainer terindikasi jentik dengan $\mathrm{HI} 20 \%$. 
WMJ (Warmadewa Medical Journal), Vol. 2 No. 2, November 2017, Hal. 67

Tabel 6 . Tabel Pemantauan Jentik Berkala Dasawisma 3

\begin{tabular}{|c|c|c|c|c|c|c|c|c|c|}
\hline \multirow{2}{*}{$\begin{array}{c}\text { Nama } \\
\text { KK }\end{array}$} & \multirow{2}{*}{$\begin{array}{c}\text { Jumlah } \\
\text { Kontainer }\end{array}$} & \multicolumn{2}{|c|}{ Minggu ke-1 } & \multicolumn{2}{|c|}{ Minggu ke-2 } & \multicolumn{2}{|c|}{ Minggu ke- 3} & \multicolumn{2}{|c|}{ Minggu ke-4 } \\
\hline & & $\begin{array}{c}\text { Kontainer } \\
\text { Terindikasi }\end{array}$ & $\begin{array}{c}\mathrm{CI} \\
(\%)\end{array}$ & $\begin{array}{c}\text { Kontainer } \\
\text { Terindikasi } \\
\end{array}$ & $\begin{array}{l}\mathrm{CI} \\
(\%) \\
\end{array}$ & $\begin{array}{c}\text { Kontainer } \\
\text { Terindikasi } \\
\end{array}$ & $\begin{array}{l}\mathrm{CI} \\
(\%) \\
\end{array}$ & $\begin{array}{c}\text { Kontainer } \\
\text { Terindikasi } \\
\end{array}$ & $\begin{array}{l}\mathrm{CI} \\
(\%) \\
\end{array}$ \\
\hline KK 1 & 11 & 1 & 9,1 & 0 & 0 & 0 & $0 \%$ & 0 & 0 \\
\hline KK 2 & 11 & 2 & 18,2 & 1 & 9,1 & 0 & $0 \%$ & 0 & 0 \\
\hline KK 3 & 11 & 2 & 18,2 & 0 & 0 & 0 & $0 \%$ & 1 & 9,1 \\
\hline KK 4 & 11 & 4 & 36,4 & 3 & 27,3 & 0 & $0 \%$ & 0 & 0 \\
\hline KK 5 & 11 & 2 & 18,2 & 1 & 9,1 & 0 & $0 \%$ & 0 & 0 \\
\hline $\mathrm{Hol}$ & e Indeks & $100^{\circ}$ & & $60 \%$ & & $0 \%$ & & $20 \%$ & \\
\hline
\end{tabular}

Dari tabel di atas dapat dilihat bahwa dari $5 \mathrm{KK}$ binaan dasawisma 3, rata-rata pemeriksaan mencakup 11 kontainer. Hasil pemeriksaan kontainer rata-rata $5 \mathrm{KK}$ pada minggu I cukup tinggi, yaitu 20\% terindikasi jentik dengan HI $100 \%$; pada minggu II adalah 9,1\% terindikasi jentik HI
$60 \%$; pada minggu III adalah $0 \%$ kontainer terindikasi jentik dengan kontainer indeks rata-rata $0 \%$ dan $\mathrm{HI} 0 \%$; dan pada minggu ke IV, hasil pemeriksaan kontainer ratarata adalah $3,6 \%$ kontainer terindikasi jentik dengan $\mathrm{HI} 20 \%$.

Grafik 1. Trend Container Indeks Mitra

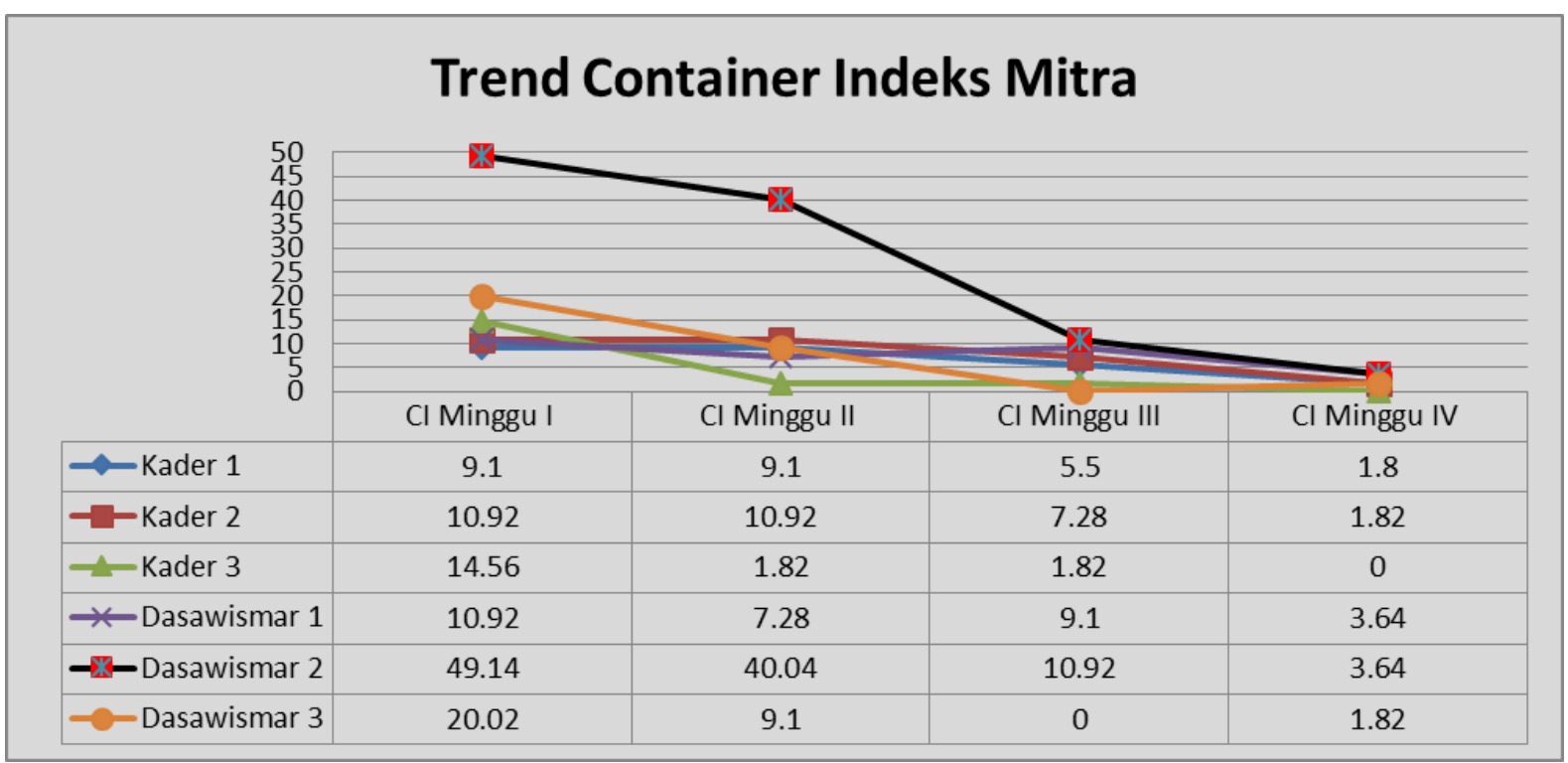

Dari grafik tersebut di atas dapat dilihat bahwa nilai Container Indeks (CI) ke enam mitra secara umum sudah mengalami penurunan dala 4 kegiatan PkM kurun waktu 4 minggu. 
Grafik 2. Trend Density Figure Mitra

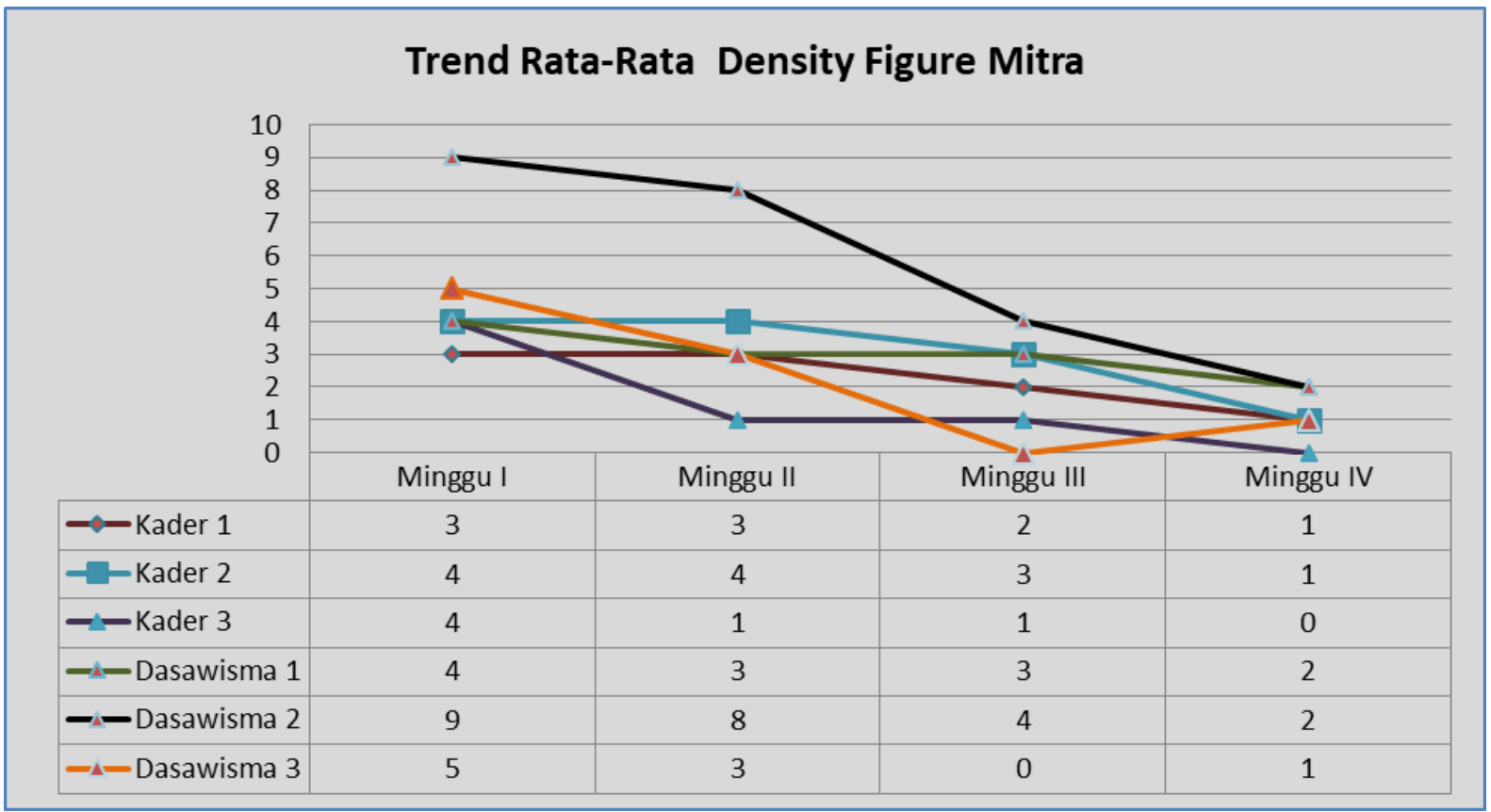

Dari grafik tersebut di atas, didapatkan bahwa rata-rata Density Figure mitra mengalami penurunan.

\section{PEMBAHASAN}

Berdasarkan hasil monitoring dan evaluasi PkM tersebut di atas, kegiatan yang diawali dengan melakukan pre-test tentang DBD menggunakan pertanyaan tentang cara pencegahan serta penyuluhan mampu meningkatkan pengetahuan dan sikap mitra tentang DBD dari nilai rata-rata 7,2 menjadi 8,8. Hal ini mengindikasikan bahwa pengetahuan masyarakat tentang DBD masih rendah sebelum dilaksanakannya program. Maka tidak mengherankan bahwa tingkat ABJ selalu di bawah 95\% dari target nasional dan angka insiden DBD selalu mengalami peningkatan tiap tahun di atas target nasional.

Penelitian Lia Meilianingsih, dkk tentang pemberdayaan keluarga dalam upaya pencegahan DBD di wilayah kerja Puskesmas Cibeureum tahun 2012 yang merupakan quasi experiment study dengan desain pre test dan post test juga mendapatkan hasil bahwa penyuluhan dan pendampingan keluarga tentang DHF mampu meningkatkan pengetahuan, sikap, dan perilaku mitra secara signifikan dibandingkan kelompok kontrol dengan $p$ value 0,00 . $^{[10]}$

Kedua kelompok mitra mampu meru- muskan problem solving mandiri dalam penanggulangan DBD melalui kegiatan FGD untuk mengetahui permasalahan masyarakat di lapangan secara kualitatif. Dari hasil FGD diketahui bahwa pengetahuan mitra tentang DBD masih kurang terutama tentang pencegahan. Kedua mitra mempersepsikan bahwa sebenarnya penanggulangan DBD terutama kegiatan yang bersifat preventif harus memberdayakan masyarakat itu sendiri, dimana masyarakat ikut serta dalam program pemantauan jentik di ruang tinggalnya masing-masing dan perangkat desa/perangkat kesehatan hanya bertugas melakukan monitoring dan evaluasi. Selama ini masyarakat belum pernah dilibatkan secara aktif dalam tindakan pencegahan DBD seperti menjadi surveilans jentik mandiri maupun melakukan PSN rutin. Kegiatan surveilans jentik hanya dilakukan oleh jumantik dan PSN baru berupa himbauan kepada masyarakat.

Kegiatan $\mathrm{PkM}$ dengan memberdayakan kader dan dasawisma mampu menurunkan nilai Container Index dan Density Figure pada semua KK binaan. Secara umum dari 
4 kali Pemantauan Jentik Berkala (PJB) mingguan, nilai $\mathrm{CI}$ dan $\mathrm{DF}$ sudah mengalami penurunan. Nilai CI dengan rata -rata pemeriksaan 11 kontainer pada semua KK binaan mitra mengalami penurunan tertinggi pada dasawisma 2. Hal ini dikarenakan paling tingginya $\mathrm{CI}$ pada $\mathrm{KK}$ binaan dasawisma 2 sebelum diadakannya program karena rendahnya tingkat pengetahuan KK binaan terhadap pencegahan DBD. Nilai Density Figure (DF) pada semua KK binaan sebelum program berada di kisaran angka 3-9, bervariasi dari kepadatan jentik sedang dan kepadatan jentik sangat tinggi. Setelah dilakukannya program surveilans jentik mingguan dan PSN berkala, nilai DF pada semua KK binaan sudah mampu ditekan sampai berada di kisaran 0-2 (risiko penularan rendah). Hal ini mengindikasikan sudah berjalan baiknya Komunikasi Informasi dan Edukasi (KIE) tentang Pemberantasan Sarang Nyamuk yang dilakukan setiap akhir PJB.

Beberapa penelitian juga mendukung adanya pemberdayaan jumantik swadaya untuk menurunkan nilai CI dan ABJ. Salah satunya adalah penelitian Rizki Mubaroh tahun 2013 di Kelurahan Danyang Purwodadi dengan metode one group pre-post test design terhadap 231 sampel menunjukkan bahwa terdapat perbedaan yang bermakna nilai ABJ DBD sebelum dan sesudah penggerakkan Jumantik swadaya dengan $\mathrm{p}=0,000^{[11]}$

Penelitian lain yang mendukung adalah penelitian crossectional Rachman Rosidi, dkk yang menemukan bahwa faktor penggerakkan PSN mandiri mampu menurunkan ABJ di Kecamatan Sumberjaya, Kabupaten Majalengka Jawa Barat dengan $p=0,000^{[12]}$.

\section{SIMPULAN}

Kegiatan PkM melalui FGD untuk menentukan problem solving dari masyarakat itu sendiri dapat menjadi intervensi primer dalam pemecahan permasalahan tentang DBD di Banjar Menak. Program penanggulangan penyakit DBD dengan menekankan pada metode pelatihan dan pendampingan salah satu perangkat desa (kader dan dasawisma) untuk mendampingi $\mathrm{KK}$ binaan selanjutnya dapat meningkatkan tingkat pengetahuan dan keterampilan, serta kemandirian KK dalam melakukan PSN yang secara statistik dapat menekan nilai Container Indeks (CI) dan Density Figure (DF) di Banjar Menak, Desa Tulikup, Kabupaten Gianyar dalam monitoring berkala kurun waktu 4 minggu.

Diharapkan selanjutnya kader dan dasawisma yang sudah terlatih dapat menjadi ujung tombak memberdayakan KK binaan untuk melatih $\mathrm{KK}$ lainnya secara terstruktur sehingga dapat meningkatkan Angka Bebas Jentik ABJ di wilayah Banjar Menak pada khususnya dan Kabupaten Gianyar pada umumnya.

\section{UCAPAN TERIMAKASIH}

Kami mengucapkan terima kasih kepada Universitas Warmadewa, Kepala Banjar Menak dan Kepala Desa Tulikup, Kabupaten Gianyar, provinsi Bali dan mitra kader serta Dasawisma yang telah membantu menyelesaikan kegiatan PkM ini.

\section{DAFTAR PUSTAKA}

1. Badan Pusat Statistik Kabupaten Gianyar. Data Kependudukan Kabupaten Gianyar. BPS Gianyar. Gianyar; 2010.

2. Kementrian Kesehatan RI. Profil Kesehatan Indonesia, Jakarta; 2014

3. Kementrian Kesehatan Republik Indonesia (Kemenkes RI). 2015. Profil Kesehatan Indonesia 2014. Kementrian kesehatan RI. Jakarta.

4. Candra, A.Demam Berdarah Dengue: Epidemiologi, Patogenesis, dan Faktor Risiko Penularan Dengue Hemorrhagic Fever. Demam Berdarah Dengue: Epidemiologi, Patogenesis, dan Faktor Risiko Penularan.2010; 2(2), pp.110-119.

5. Direktorat Jenderal Pemberantasan 
Penyakit Menular dan penyehatan Lingkungan. Surveilans Epidemiologi Penyakit (PEP). Edisi I. Depkes RI. Jakarta. 2003.

6. Kementrian Kesehatan Republik Indonesia (Kemenkes RI). 2011. Modul Pengendalian Demam Berdarah Dengue. Jakarta. Available from:

7. Malavige, G.N., 2004. Dengue viral infections. Postgraduate Medical Journal, 80(948), pp.588-601.

8. World Health Organization (WHO). 2011. Comprehensive Guidelines for Prevention and Control of Dengue Haemorrhagic Fever. Searo Technical Publication. New Delhi.

9. World Health Organization (WHO). 2012. Global Strategy for Dengue Prevention and Control. WHO. WHO Press. Geneva.
10. Meilianingsih, Lia. Dkk. Pemberdayaan Keluarga dalam Upaya Pencegahan Demam Berdarah Dengue melalui Pendidikan Kesehatan di Wilayah Kerja Puskesmas Cibeureum. 2012.

11. Mubarokah, Risqi. Upaya Peningkatan Angka Bebas Jentik Demam Berdarah Dengue melalui Penggerakkan Jumantik di RW 1 Kelurahan Danyang Kabupaten Purwodadi,Kabupaten Grobogan.Vol.34.2013.

12. Rosidi,Rachman dkk..Hubungan Faktor Penggerakan pemberantasan Sarang Nyamuk Demam berdarah Dengue dengan Angka Bebas jentik di Kecamatan Sumberjaya Kabupaten Majalengka, Jawa Barat. Dalam Jurnal epidemiologi ipi34607.2013 